\title{
Iron is not everything: unexpected complex metabolic responses between iron-cycling microorganisms
}

\author{
Rebecca E. Cooper ${ }^{1}$ - Carl-Eric Wegner ${ }^{1} \cdot$ Stefan Kügler ${ }^{1,2} \cdot{\text { Remington X. Poulin } \mathbb{D}^{2} \cdot \text { Nico Ueberschaar }}^{3}$. \\ Jens D. Wurlitzer ${ }^{1} \cdot$ Daniel Stettin $\mathbb{D}^{2} \cdot$ Thomas Wichard $\mathbb{D}^{2} \cdot$ Georg Pohnert $\mathbb{D}^{2} \cdot$ Kirsten Küsel $\mathbb{D}^{1,4}$
}

Received: 24 March 2020 / Revised: 30 June 2020 / Accepted: 8 July 2020 / Published online: 20 July 2020

(c) The Author(s) 2020. This article is published with open access

\begin{abstract}
Coexistence of microaerophilic Fe(II)-oxidizers and anaerobic Fe(III)-reducers in environments with fluctuating redox conditions is a prime example of mutualism, in which both partners benefit from the sustained Fe-pool. Consequently, the Fe-cycling machineries (i.e., metal-reducing or -oxidizing pathways) should be most affected during co-cultivation. However, contrasting growth requirements impeded systematic elucidation of their interactions. To disentangle underlying interaction mechanisms, we established a suboxic co-culture system of Sideroxydans sp. CL21 and Shewanella oneidensis. We showed that addition of the partner's cell-free supernatant enhanced both growth and Fe(II)-oxidizing or Fe(III)-reducing activity of each partner. Metabolites of the exometabolome of Sideroxydans sp. CL21 are generally upregulated if stimulated with the partner's spent medium, while $S$. oneidensis exhibits a mixed metabolic response in accordance with a balanced response to the partner. Surprisingly, RNA-seq analysis revealed genes involved in Fe-cycling were not differentially expressed during co-cultivation. Instead, the most differentially upregulated genes included those encoding for biopolymer production, lipoprotein transport, putrescine biosynthesis, and amino acid degradation suggesting a regulated inter-species biofilm formation. Furthermore, the upregulation of hydrogenases in Sideroxydans sp. CL21 points to competition for $\mathrm{H}_{2}$ as electron donor. Our findings reveal that a complex metabolic and transcriptomic response, but not accelerated formation of Fe-end products, drive interactions of Fe-cycling microorganisms.
\end{abstract}

\section{Introduction}

Chemical communication is often the driving force of mutualistic interactions within microbial communities

Supplementary information The online version of this article (https:// doi.org/10.1038/s41396-020-0718-z) contains supplementary material, which is available to authorized users.

Kirsten Küsel

kirsten.kuesel@uni-jena.de

1 Institute of Biodiversity, Aquatic Geomicrobiology, Friedrich Schiller University Jena, Dornburger Strasse 159, 07743 Jena, Germany

2 Institute of Inorganic and Analytical Chemistry, Friedrich Schiller University Jena, Lessingstr. 8, 07743 Jena, Germany

3 Mass Spectrometry Platform, Faculty of Chemistry and Earth Sciences, Friedrich Schiller University Jena, Humboldstr. 8, 07743 Jena, Germany

4 German Centre for Integrative Biodiversity Research (iDiv) Halle-Jena-Leipzig, Deutscher Platz 5e, 04103 Leipzig, Germany
$[1,2]$. The excreted metabolites can positively affect the growth of co-existing organisms by providing key metabolites produced by one partner and needed by the other [38]. The reciprocal benefits resulting from the excretion of metabolites indicate that while each partner invests metabolic resources, they both gain something from the other mutualistic partner [9-11]. Such mechanisms can not only control growth but also spatial distribution within the community in cases of heterogeneous environments. Synchronization of lifestyles is particularly important for mutualism interaction based on the partner's end products for energy production [7, 12, 13].

Fe-cycling microorganisms are often found coexisting in nature. This is explained by the needs of both the ferrous iron $[\mathrm{Fe}(\mathrm{II})]$ oxidizer and ferric iron [Fe(III)] reducer to have sufficient exposure to electron donors and acceptors. For lithoautotrophic Fe(II)-oxidizers, including Gallionella sp. and Sideroxydans lithotrophicus ES-1, Fe(II) serves as an electron donor under micro-oxic conditions, thereby providing ample reducing equivalents for the assimilation of carbon [14-17]. Microbial Fe(II) oxidation facilitates the 
rapid precipitation of $\mathrm{Fe}(\mathrm{III})$ oxy-hydroxide nanoparticles $[18,19]$, which are preferred by anaerobic heterotrophic $\mathrm{Fe}$ (III)-reducers, such as Shewanella spp. or Geobacter spp., due to their small mineral size [20-23]. For Fe-cycling, at least temporary access to oxygen, or to oxidized compounds, is necessary for the renewal of the Fe(III) pool $[14,16]$. In wetlands or peatlands, this renewal is mediated by water table fluctuations, bioturbation, or the release of oxygen via plant roots [24] which allows interaction between Fe-cycling microorganisms regardless of their different demands for $\mathrm{O}_{2}$. Production of $\mathrm{Fe}(\mathrm{III})$-chelating ligands like riboflavins by Shewanella spp. or the presence of natural organic matter with $\mathrm{Fe}$-complexing or electron shuttling properties can overcome spatial restrictions and speed up microbial activities $[25,26]$.

Interestingly, a shared homology is observed between the genes encoding the $\mathrm{Fe}$ (III) reduction machinery located at the cell surface in $S$. oneidensis and the genes encoding the Fe(II) oxidation machinery of Sideroxydans lithotrophicus ES-1 [17, 27]. In S. oneidensis, the Mtr machinery, comprised of the $m \operatorname{tr} A B C$ gene cluster, is a porin-cytochrome complex in the outer membrane enabling the electron transport through the outer membrane via various hemes to $\mathrm{Fe}(\mathrm{III})[28,29]$. The MtoAB complex of Sideroxydans is homologous to MtrA and MtrB and functions in the same manner, forming a porin-cytochrome complex. Thus, we hypothesized that in parallel to the exchange of genetic information, additional mutualistic interactions based on the exchange of each partner's exometabolites may have been established between these $\mathrm{Fe}$ cycling partner organisms.

To elucidate these interaction mechanisms, co-culture systems are needed to facilitate downstream analytics on both the transcriptome and metabolome levels. But, cocultivation of Fe-cycling microorganisms is very challenging due to their different lifestyles for $\mathrm{O}_{2}$. We selected two model microorganisms, the microaerophilic, autotrophic Fe(II)-oxidizer Sideroxydans sp. CL21 isolated from Schlöppnerbrunnen fen [15] and closely related to Sideroxydans lithotrophicus ES-1 [17], and the facultative anaerobic $\mathrm{Fe}(\mathrm{III})$-reducer $S$. oneidensis isolated from Lake Oneida, NY [30]. First, we optimized incubation conditions that allow both partners to thrive simultaneously. The co-cultivation design allowed us to explore the influence of exposure to the partner's end product for energy production by analyzing changes in 16S rRNA gene copies, RNA-seq analysis, and metabolomics. We hypothesized that co-cultivation will lead to an accelerated iron wheel (Fe(II) $\leftrightarrow \mathrm{Fe}(\mathrm{III})$ ), because the Fe-cycling machinery would be the most affected during cocultivation. In addition, we tested the effect of the exometabolome of one partner organism on the activity of the other.

\section{Materials and methods}

\section{Bacterial strains and cultivation conditions}

Sideroxydans sp. CL21 and S. oneidensis were cultivated in liquid supernatant exchange, monoculture, and co-culture incubations [15, 30-32] using ATCC medium 2672 (modified Wolfe's minimal media (MWMM)) amended with 10 $\mathrm{mM}$ MES buffer ( $\mathrm{pH}$ 6.3) unless otherwise noted. Sideroxydans sp. CL21 stock cultures grown in semi-solid gradient tubes containing $0.15 \%$ agarose-stabilized MWMM (Biozyme LE Agarose; Biozyme Scientific $\mathrm{GmbH}$, Hessisch Oldendorf, DE) and zero-valent $\mathrm{Fe}\left(\mathrm{Fe}^{(0)}\right)$ were used as inoculum ( $1 \mathrm{~mL}$ inoculum $100 \mathrm{~mL}^{-1}$ media) in these incubations. Zero-valent iron powder is often used as the source of $\mathrm{Fe}$ (II) to cultivate $\mathrm{Fe}$ (II)-oxidizing bacteria [33], and we observed enhanced biomass during cultivation of Sideroxydans sp. CL21 in semi-solid gradient tubes, in comparison to $\mathrm{FeS}$ or $\mathrm{FeCl}_{2} . \mathrm{Fe}^{(0)}$ also provided the best $\mathrm{Fe}$ source for the liquid co-culture incubations. S. oneidensis overnight cultures were grown aerobically in Luria-Bertani medium. $1 \mathrm{~mL}$ was transferred into $125 \mathrm{~mL}$ serum bottles containing $60 \mathrm{~mL}$ MWMM amended with $18 \mathrm{mM}$ lactate and grown aerobically at room temperature. $2 \mathrm{~mL}$ of MWMM-grown S. oneidensis was harvested after $\sim 14 \mathrm{~h}$ (late exponential growth), centrifuged $(10,000 \mathrm{~g}, 5 \mathrm{~min})$, washed twice, resuspended in $2 \mathrm{~mL}$ MWMM, and used as inoculum (final concentration: $\sim 2 \times 10^{5}$ cells $\mathrm{mL}^{-1}$ ) for the above mentioned incubations.

\section{Monoculture and co-culture incubations}

Monocultures and co-cultures were set up in triplicates in $125 \mathrm{~mL}$ serum bottles with an $\mathrm{Fe}^{(0)}$-containing bottom-layer plug (10 mL MWMM, 3\% agarose (Biozyme LE Agarose), $\left.1 \mathrm{~g} \mathrm{~L}^{-1} \mathrm{Fe}^{(0)}\right)$. Following solidification, $60 \mathrm{~mL}$ MWMM amended with $1 \mathrm{mM}$ lactate was dispensed on top and continuously flushed with an $\mathrm{N}_{2}: \mathrm{CO}_{2}: \mathrm{O}_{2}, 78: 20: 2$, (flow rate: $300 \mathrm{~mL} \mathrm{~min}^{-1}$ ) gas mixture to maintain a micro-oxic environment (Fig. 1a). Cells were harvested at four timepoints ( $6 \mathrm{~h}, 3 \mathrm{~d}, 6 \mathrm{~d}, 9 \mathrm{~d})$, centrifuged) and stored at $-80^{\circ} \mathrm{C}$. 6 d samples were selected for RNA-Seq.

\section{Cell-free supernatant exchange experiment}

Supernatant exchange experiments were set up in triplicates according to Mori et al. [34], with the following modifications: Sideroxydans sp. CL21 and S. oneidensis cultures were grown in $200 \mathrm{~mL}$ MWMM amended with $1 \mathrm{mM}$ lactate and $1.2 \mathrm{mM} \mathrm{FeSO}_{4}$ or $10 \mathrm{mM}$ hydrous $\mathrm{Fe}$ (III) oxyhydroxide, respectively, for 4 days with shaking at room temperature. Cultures were centrifuged, filtered $(0.22 \mu \mathrm{m})$, cell-free supernatant was collected, and 


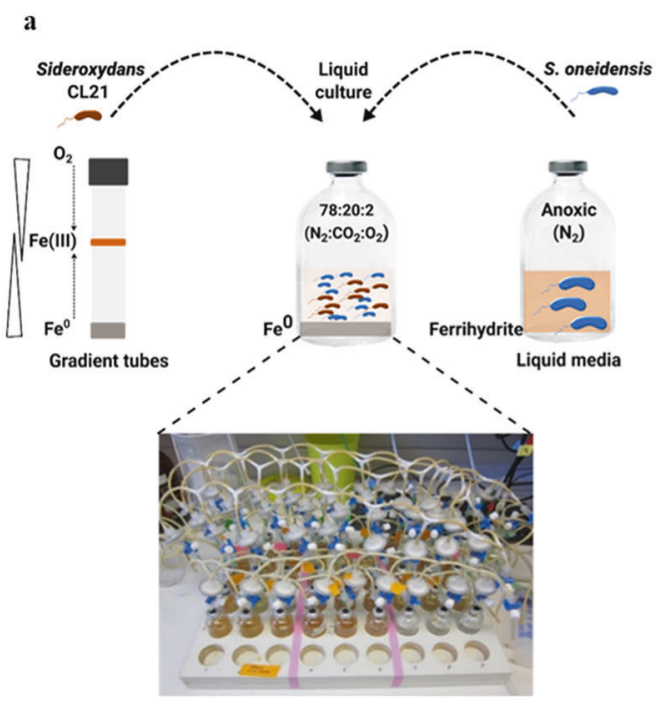

b

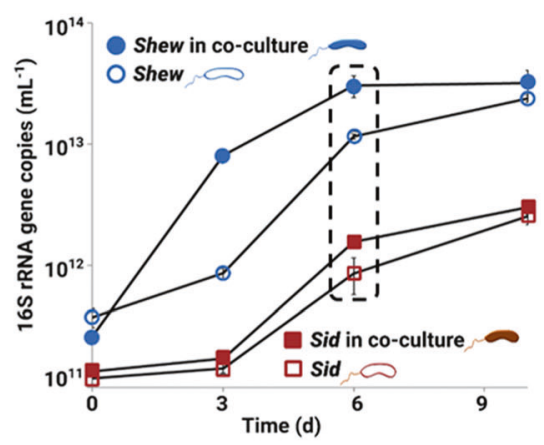

Fig. 1 Co-culture incubation setup of Sideroxydans CL21 and $S$. oneidensis grown under microoxic conditions. a Pre-cultures were grown under standard optimized conditions either in gradient tubes or in liquid media prior to inoculation of co-culture incubations. b Both organisms can also grow in monoculture in this incubation set-up. 16S rRNA gene copy abundances of Sideroxydans CL21 or S. oneidensis showing growth in monoculture and in co-culture over 9 days of incubation. Data points represent mean abundances $(n=3)$ from either
Sideroxydans CL21 monocultures (open squares) or Sideroxydans CL21 in co-culture (closed squares) and mean abundances $(n=3)$ from $S$. oneidensis monocultures (open circles) or S. oneidensis in coculture (closed circles). In $\mathbf{b}$, a box with dashed lines is used to indicate that samples from the $6 \mathrm{~d}$ time point were used for RNA-seq. Error bars represent standard deviation in triplicate incubations. In some cases, error bars are smaller than the symbols.

mixtures $\left(5 \times 10^{8}\right.$ to $5 \times 10^{2}$ copies; $R^{2}$ value $=$ $0.999-1.000$ ) were linear for both primer sets. The qPCR performed with efficiencies ranging from 80 to $90 \%$.

\section{Sample prep for RNA-Seq analysis}

Total RNA was extracted from three biological replicates from Sideroxydans sp. CL21 and S. oneidensis monoculture and co-culture incubations using the phenol-chloroform extraction method adapted from Wegner et al. [37]. Equimolarly pooled cDNA libraries were sequenced in pairedend mode $(2 \times 150 \mathrm{bp})$ on an Illumina NextSeq 500 platform by LGC Genomics (Berlin, DE).

\section{Transcriptome data processing and analysis}

The quality of raw, demultiplexed RNA-Seq datasets was inspected using FastQC (v0.11.7) [38]. Quality trimming (settings: $\operatorname{minlen}=75, \quad$ qtrim $=\mathrm{rl}, \quad \mathrm{ktrim}=\mathrm{rl}, \quad k=25$, mink $=11$, trimq $=20, \quad$ qtrim $=\mathrm{rl}$ ) and adapter sequence removal was done with bbduk (v38.26) [39] using the included set of common sequence contaminants and adapters. rRNA-derived and non-coding RNA sequences were filtered out with sortmerna (v2.1) [40] and its precompiled SILVA databases [41] and Rfam [42]. The remaining, putatively mRNA-derived sequences were mapped onto the available $S$. oneidensis reference genome 
a

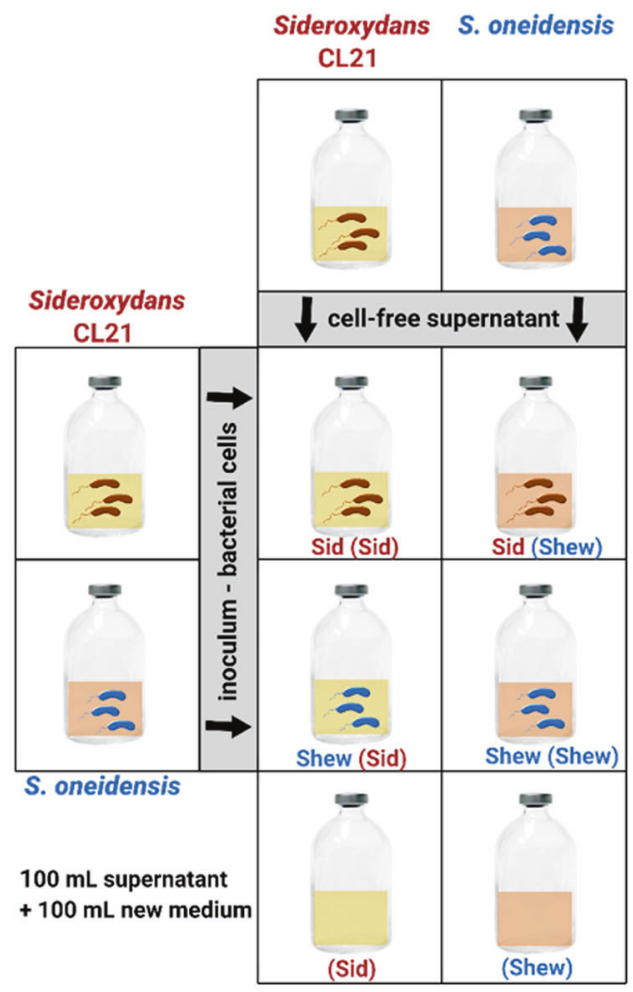

b

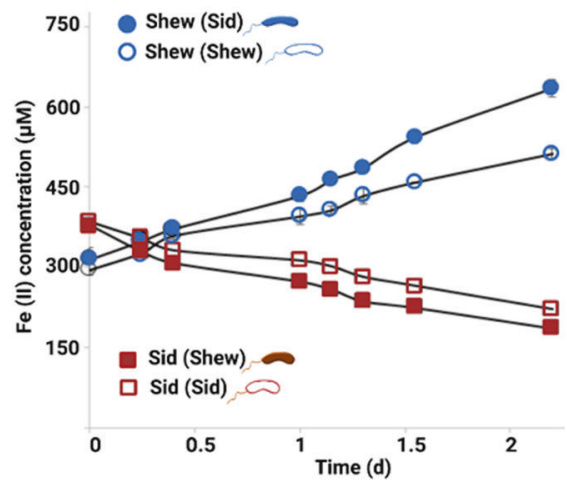

C

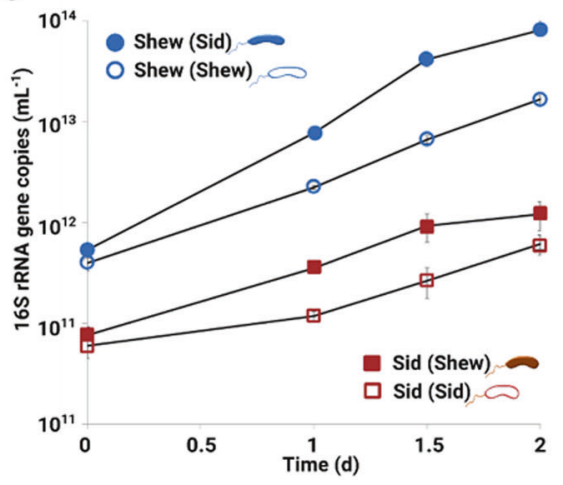

supernatant or to monitor $\mathrm{Fe}(\mathrm{III})$ reduction in incubations with $S$. oneidensis amended with either Sideroxydans CL21 [Shew (Sid)] or S. oneidensis [Shew (Shew)] cell-free supernatant. c qPCR assays were used to determine mean abundances of $16 \mathrm{~S}$ rRNA gene copies in triplicate samples from cell-free supernatant exchange incubations. Error bars represent standard deviation in triplicate incubations $(n=$ 3 ). In some cases, error bars are smaller than the symbols.

\section{Metabolomics methods}

\section{Sample preparation for metabolomic profiling}

Sample preparation was conducted in triplicate as described previously [34], unless otherwise noted. Briefly, $50 \mathrm{~mL}$ of liquid cultures were centrifuged $(4000 \mathrm{~g})$ and extracted using Strata- $\mathrm{X}^{\oplus}$ polymeric reverse phase cartridges $(200 \mathrm{mg}$ adsorbent; Phenomenex, Torrance, CA, USA). Sample preparation was performed in an anaerobic chamber to minimize $\mathrm{Fe}(\mathrm{II})$ oxidation and subsequent $\mathrm{Fe}(\mathrm{III})$ precipitation. (NOTE: in previous experiments, precipitation of $\mathrm{Fe}(\mathrm{III})$ during sample preparation resulted in completely dissimilar metabolite profiles-data not shown). Samples were measured in a randomized sample list immediately after preprocessing. 


\section{GC/MS measurement}

GC/MS metabolomics analysis was conducted on 3 and $6 \mathrm{~d}$ supernatant exchange samples using a high resolution QExactive-GC electron impact (EI) orbitrap mass spectrometer (Thermo Scientific), with gas-chromatographic separations implemented on a Trace 1310 equipped with TriPlus RSH autosampler. A TG-5SILMS column (length $=30 \mathrm{~m}$; inner diameter $=0.25 \mathrm{~mm}, 0.25 \mu \mathrm{m}$ film; Thermo Scientific) was used. Column operation parameters and GCOrbitrap settings used are described in the supplementary methods.

\section{XCMS metabolomic analysis}

The XCMS data processing was carried out using -cdf files, which were converted from the Thermo RAW-files using the Xcalibur 3.0.63 (Thermo Scientific) onboard file converter. Processing was carried out using XCMS Server version 3.01.01. Pre-defined settings were used for GCmeasurement "Single Quad (matched filter)," except, retention time correction was removed [49]. Parameters used are listed in Table S2.

\section{UHPLC/HRMS measurement and spectra acquisition}

Ultra high performance liquid chromatography (UHPLC) coupled with high resolution MS (HRMS) of both for untargeted and targeted ( $\gamma$-aminobutanoic acid (GABA) and zinc) metabolites was performed using an UltiMate HPG3400 RS binary pump (Thermo Scientific, Bremen, Germany) and WPS-3000 autosampler (Thermo Scientific) equipped with a $25 \mu \mathrm{L}$ injection syringe and $100 \mu \mathrm{L}$ sample loop. Detailed parameters used are described in the supplementary methods.

\section{GC/MS data processing and annotation}

Using an in-house R-script [50], detected masses were deconvoluted via peak-shape comparison to potential metabolites and reduced in number to only include potential metabolites containing $\geq 20$ fragments. Potential metabolites present in blanks and media controls $(<$ fivefold increase or decrease relative to bacterial samples) were removed (Table S3). The remaining potential metabolites were logtransformed and auto-scaled via Metaboanalyst 4.0 [51] to yield heatmaps with the 15 most dysregulated metabolites. Unknown metabolites were identified by comparing fragmentation patterns to known compounds in the NIST/EPA/ NIH EI Mass Spectral Library NIST 17 (copyright United States Department of Commerce) searched with the NIST Mass Spectral Search Program v.2.3a nd Golm Metabolome Database library [52]. Metabolites with match scores $>700$ were tentatively identified and compounds with multiple match score hits $>600$ were labeled by compound class. During the analysis of supernatant exchange samples, an $S$. oneidensis control (Shew(Shew)) sample (6 d) was also removed from the analysis due to errors during spectral profiling.

\section{UHPLC/HRMS data processing and quantification}

Quan Browser (XCalibur 3.0.63) (Thermo Scientific) was used for peak detection and integration for GABA and a detected zinc compound with the following settings: mass tolerance $=10$ ppm, peak detection algorithm $=\mathrm{ICIS}$; smoothing points $=1$; baseline window $=40$; area noise factor $=15$; peak noise factor $=10$; peak high $=5 \%$, tailing factor $=2.5$ and peak detection method $=$ nearest RT. Each biological sample was measured in triplicate using a randomized sample list. The presence of GABA in the samples was confirmed by comparison to GABA standards. In order to identify metalloenzyme complexes, for example zinc complexes, MICP was applied to the UHPLC/HRMS data of the supernatant extracts and the zinc compounds were identified based on the natural isotopic pattern. The single isotopes of the metal-complexes were resolved due to a resolution of 280.000 at $\mathrm{m} / \mathrm{z}=200$, e.g., for ${ }^{64} \mathrm{Zn}-,{ }^{66} \mathrm{Zn}-$, ${ }^{67} \mathrm{Zn}$-, and ${ }^{68} \mathrm{Zn}$-complexes for one substance. The identification is based on the mass differences between the single isotopic peaks of the substance (with an error $<1 \mathrm{ppm}$ ) and the intensity of the mass peaks according to the abundance of the natural zinc isotopes.

\section{Results}

\section{Merging lifestyles of S. oneidensis and Sideroxydans sp. CL21}

S. oneidensis can be grown easily anaerobically in liquid media with $\mathrm{Fe}$ (III) as a terminal electron acceptor. However, the microaerophilic Sideroxydans sp. CL21 prefers growing in so-called "gradient" tubes filled with semi-solid media, an $\mathrm{Fe}(\mathrm{II})$ source in the bottom, and $\mathrm{O}_{2}$ supplied in the headspace. Opposing $\mathrm{Fe}$ and $\mathrm{O}_{2}$ gradients allow growth at a depth with optimal $\mathrm{O}_{2}$ concentrations of $20-40 \mu \mathrm{M}$ [53]. Microbial Fe(II)-oxidation leads to the formation of a distinct orange ring of precipitated $\mathrm{Fe}(\mathrm{III})$ (oxy)hydroxides. However, the semi-solid media poses complications for the envisioned metabolomics profiling. To identify metabolites produced and secreted by each individual partner, we had to establish a suboxic liquid media setup that enables the growth of both Sideroxydans sp. CL21 and S. oneidensis in monocultures and co-cultures. In total we tested 48 combinations of media, carbon sources, buffer type, and $\mathrm{Fe}$ 
sources, bottle sizes, and headspace conditions to land on the best setup for our incubations (Fig. 1a): MWMM supplemented with MES buffer, lactate, and $\mathrm{Fe}^{(0)}$ provided in a semi-solid media plug at the bottom, and a headspace of $\mathrm{N}_{2}$ : $\mathrm{CO}_{2}: \mathrm{O}_{2}(78: 20: 2)$ that is constantly flushed through the bottles. Under these conditions, $\mathrm{Fe}^{(0)}$ reacts slowly with water forming $\mathrm{Fe}(\mathrm{II})$ and $\mathrm{H}_{2}$ (anaerobic corrosion) and the released $\mathrm{Fe}$ (II) is slowly abiotically oxidized to $\mathrm{Fe}(\mathrm{III})$. Consequently, both $\mathrm{Fe}$ (II) and $\mathrm{Fe}(\mathrm{III})$ are continuously provided, and microbial activity should speed up the production of each $\mathrm{Fe}$ species. Unlike other $\mathrm{Fe}$ minerals, $\mathrm{Fe}^{(0)}$ is not ubiquitous in environmental systems and $\mathrm{Fe}^{(0)}$ is most often applied to groundwater and soil environments for in situ remediation of metalloid-contaminated sites. However, amendment with $\mathrm{Fe}^{(0)}$ results in enrichment of $\mathrm{Fe}(\mathrm{III})$ reducing and $\mathrm{Fe}(\mathrm{II})$-oxidizing microorganisms [54-58].

\section{Exometabolome stimulates growth and activity of each partner}

First, we performed supernatant exchange experiments (Fig. 2a). Amendments with the partner's cell-free supernatant led to enhanced rates of the production and consumption of $\mathrm{Fe}(\mathrm{II})$. Rates of $\mathrm{Fe}(\mathrm{II})$ oxidation by Sideroxydans sp. CL21 over 2 days increased from 4.3 to $5.5 \mu \mathrm{M} \mathrm{h}^{-1}$ ( $t$-test, $p=0.002$ ) when amended with $S$. oneidensis cell-free supernatant and $\mathrm{Fe}(\mathrm{III})$ reduction rates of $S$. oneidensis increased from 4.9 to $7.3 \mu \mathrm{M} \mathrm{h}^{-1}$ (t-test, $p=$ 0.007) following amendment with Sideroxydans sp. CL21 cell-free supernatant (Fig. 2b, Supplementary Table S4). $16 \mathrm{~S}$ rRNA gene copy numbers increased one order of magnitude in Sideroxydans sp. CL21 [Sid(Shew)] and two orders of magnitude in S. oneidensis [Shew(Sid)] after 3 days of batch incubation compared with its control Sid (Sid) or Shew(Shew), respectively (Fig. 2c).

These stimulatory effects show that diffusive metabolites are beneficial for this mutualistic relationship, such that metabolites from one species promotes growth and other metabolic processes, such as iron oxidation or reduction, of the other species. To identify potential chemical mediators, comparative (untargeted) metabolomic profiling was performed after 3 and 6 days. After three days of incubation with S. oneidensis supernatant, an increase in Sideroxydans sp. CL21 excretion was detected (Fig. 3a, Supplementary Table S3). A phenylketone was putatively identified by analyzing the accurate mass $(309.0972 \mathrm{~m} / \mathrm{z})$ as a dehydrated fragment of a hydrated phenylketone with accurate mass $(327.1077 \mathrm{~m} / \mathrm{z})$ via comparison with the NIST database (match scores of 631 and 673 respectively). The accurate mass of the dehydrated fragment fits within $1.4 \mathrm{ppm}$ error according to exact mass. After 6 days of incubation with $S$. oneidensis cell-free supernatant, $88 \%$ of the top 25 dysregulated metabolites, meaning metabolites with concentrations affected by treatment, (out of 473 annotated peaks), were more abundant in the exometabolome of Sideroxydans sp. CL21 exposed to S. oneidensis supernatant (Fig. 3b, Supplementary Table S3). S. oneidensis exposed to the supernatant of Sideroxydans sp. CL21 also exhibited increased excretion with a total of 321 annotated compounds. A mixed metabolic response was observed, with only $52 \%$ of the top 25 most dysregulated compounds more abundant after 3 days. After 6 days, all 25 of the top dysregulated compounds were less abundant in $S$. oneidensis exposed to Sideroxydans sp. CL21 supernatant suggesting that these metabolites were not being produced at similar rates as in monocultures. For example, a dihydroxyindole was putatively identified (accurate mass $365.1655 \mathrm{~m} / \mathrm{z}$, which fits $-0.8 \mathrm{ppm}$ according to exact mass; NIST database R. match 674 and match score 658). An overall decrease in excretion at day 6 relative to day 3 was also exhibited, as evidenced by only 151 annotated compounds detected at day 6. Efforts to identify additional specific metabolites whose concentrations differed most were unsuccessful, which is in accordance with a high degree of secondary metabolite production that are not annotated in standard libraries (Fig. 3, Supplementary Table S3).

\section{RNA-Seq profiling of co-cultures show unexpected patterns of differentially expressed genes}

Sideroxydans sp. CL21 and S. oneidensis were grown together over 9 days to cover potential mutually induced responses and effects of physical contact with the partner (Fig. 1a). Co-culturing was beneficial to growth, as the increase in 16S rRNA gene copies of both organisms was higher in co-cultures compared with monocultures (Fig. 1b) with the highest increase between 3 and 6 days. Thus, maximal 16S rRNA gene copies in co-cultures coupled with increased $\mathrm{Fe}$-cycling rates in supernatant exchange experiments (Table S4) led to the selection of day 6 for RNA-Seq analyses.

The overall transcriptome profiles of the monocultures demonstrated that genes involved in $\mathrm{Fe}(\mathrm{II})$ oxidation (i.e., the Sideroxydans sp. CL21 mto gene cluster) or Fe(III) reduction (i.e., the $S$. oneidensis $m t r$ gene cluster) were highly expressed (ranging from 6.2-9.5 $\log _{2} \mathrm{CPM}$ ), showing that not only Sideroxydans sp. CL21, but also $S$. oneidensis were utilizing $\mathrm{Fe}$ under suboxic conditions. Both monoculture gene expression profiles were dominated by genes encoding proteins linked to core metabolic functions, ribosomal proteins, RNA polymerase subunits, and ATP synthase subunits (Fig. 4a, Supplementary Tables S5, S6). Genes encoding a lactate permease and lactate dehydrogenase were highly expressed, which indicated $S$. oneidensis is using lactate as the electron donor (Supplementary 
a

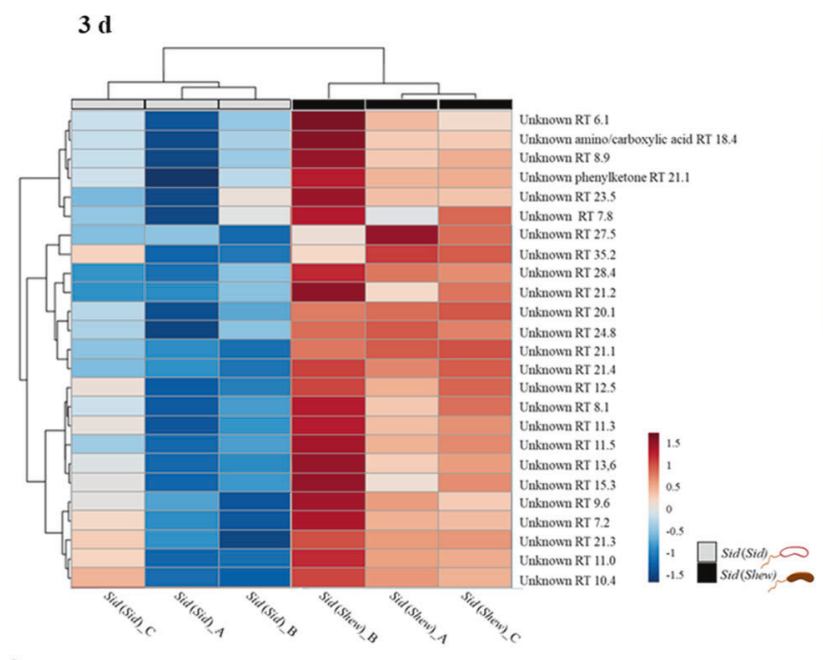

c

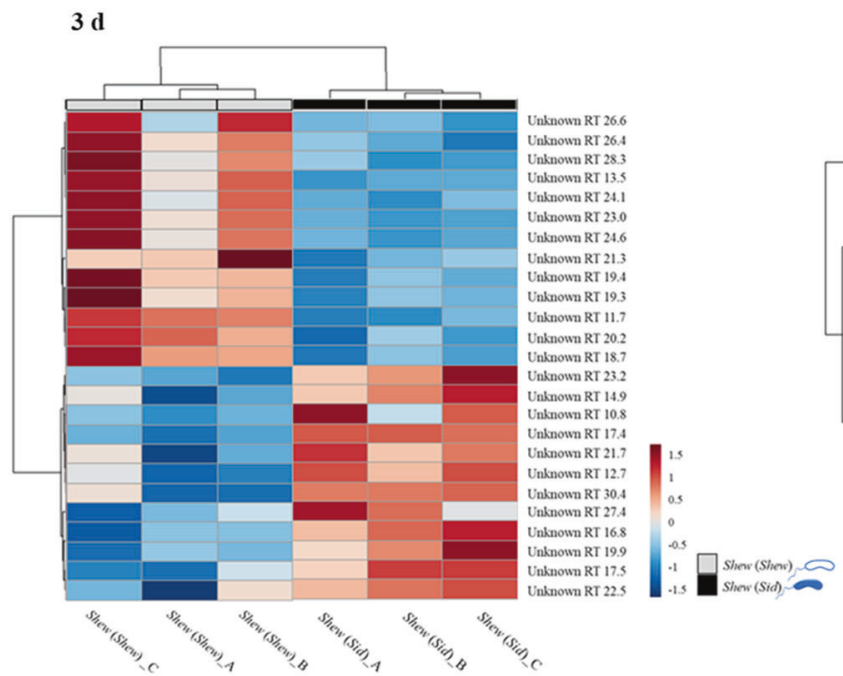

Fig. 3 GC/MS based untargeted metabolome profiling of cell-free supernatant exchange experiments. Comparative analyses of the exometabolites produced by Sideroxydans sp. CL21 incubated with its' own cell-free supernatant $(50 \% v / v)(\operatorname{Sid}(\mathrm{Sid}))$ versus Sideroxydans sp. CL21 incubated with the cell-free supernatant of $S$. oneidensis $(50 \% v / v)(\operatorname{Sid}($ Shew $))$ after a $3 \mathrm{~d}(\mathbf{a})$ and $6 \mathrm{~d}(\mathbf{b})$ incubation period

Table S5). Genes involved in flagellar motility were also highly expressed in both organisms (Supplementary Tables S5, S6). In the case of S. oneidensis, we detected notably high gene expression values (7.5-9.0 $\left.\log _{2} \mathrm{CPM}\right)$ for genes of the putrescine degradation pathway (Table 1, Supplementary Table S5). In the Sideroxydans sp. CL21 gene expression profiles, we identified multiple genes for cation efflux system proteins that featured particular high gene expression values $\left(\log _{2} \mathrm{CPM}>10\right)$ (Supplementary Table S5). A cluster of NiFe-hydrogenases-related genes, including genes for hydrogenase subunits and proteins involved in hydrogenase assembly and maturation was uniformly and highly expressed with $\log _{2} \mathrm{CPM}$ values b

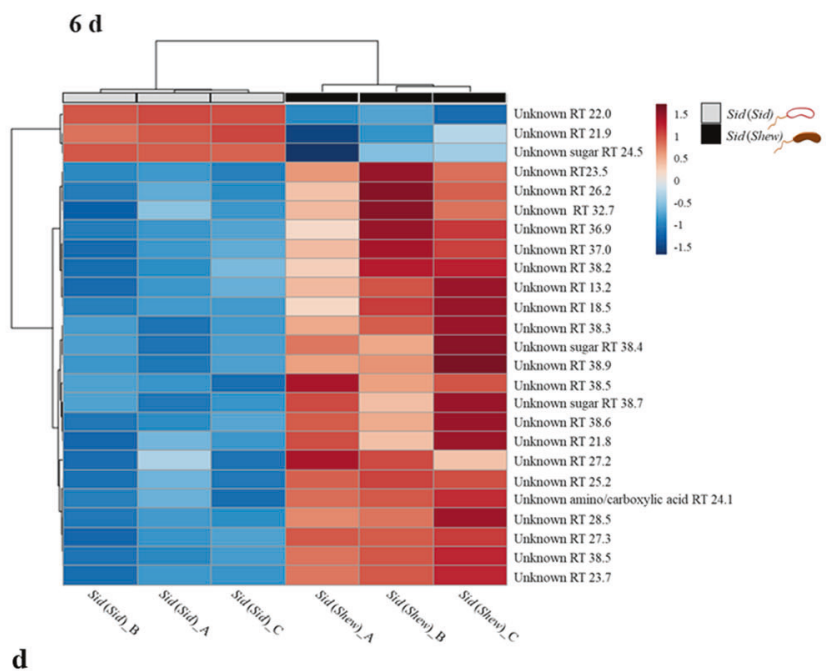

$6 d$

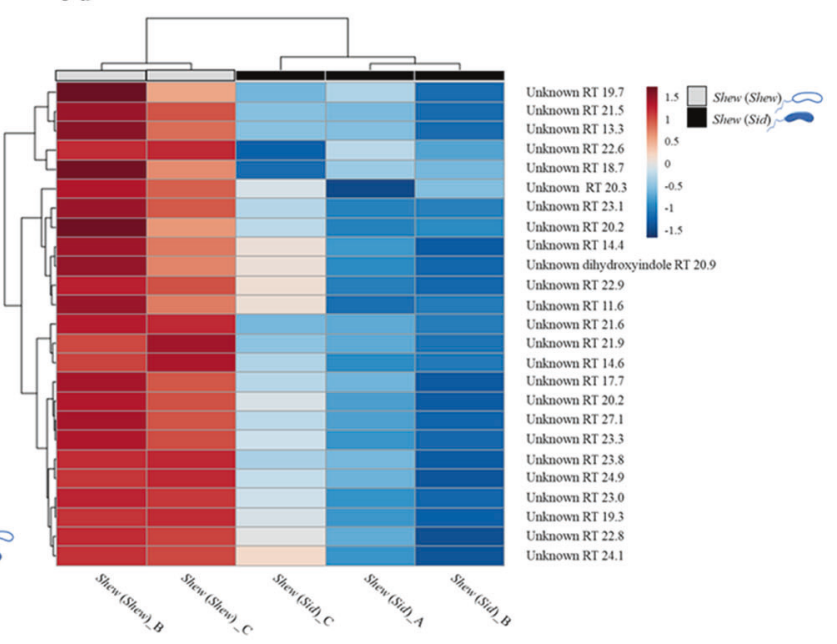

were conducted. Similarly, comparative analyses of the exometabolites produced by $S$. oneidensis incubated with its' own cell-free supernatant $(50 \% v / v)($ Shew(Shew)) versus S. oneidensis incubated with the cell-free supernatant of Sideroxydans sp. CL21 (50\% v/v) (Shew (Sid)) after a $3 \mathrm{~d}(\mathbf{c})$ and $6 \mathrm{~d}(\mathbf{d})$ incubation period were conducted. “_A, _B, or _C" corresponds to one replicate $(n=3)$.

ranging between 7 and 10 (Table 2, Supplementary Table S6). Genes involved in the Calvin-Benson-Bessham pathway, which reduces 3-phosphoglycerate via RubisCO (ribulose-1,5-bisphosphate carboxylase/oxygenase), were highly expressed in Sideroxydans sp. CL21, such that genes encoding the proteins $\mathrm{CbbO}$ and $\mathrm{CbbQ}$ were upregulated $\left(\log _{2} \mathrm{FC} 1.02-1.31\right)$. The presence of both the small and large forms of RubisCO suggests a high tolerance to fluctuating $\mathrm{O}_{2}$ concentrations [17]. Also, genes encoding a lactate dehydrogenase and permease were highly expressed, thus implicating possible simultaneous use of inorganic and organic carbon during co-cultivation (Supplementary Table S6). 
Fig. 4 RNA-seq profiling reveals key metabolic pathways driving interactions in co-culture. Graphical representation of overall gene expression in Sideroxydans sp. CL21 and $S$. oneidensis monocultures (a) compared wiith the differential gene expression during co-cultivation b are shown. Differentially expressed genes were determined by analysis of RNAseq data from triplicate coculture (Sideroxydans CL21+ $S$. oneidensis) and monoculture batch incubations at the $6 \mathrm{~d}$ time point (see Fig. 1). $\log _{2} \mathrm{CPM}$ $(\mathrm{CPM}=$ counts per million) values represent a normalized measure for gene expression based on the mRNA-derived sequences that were mapped onto genes. a

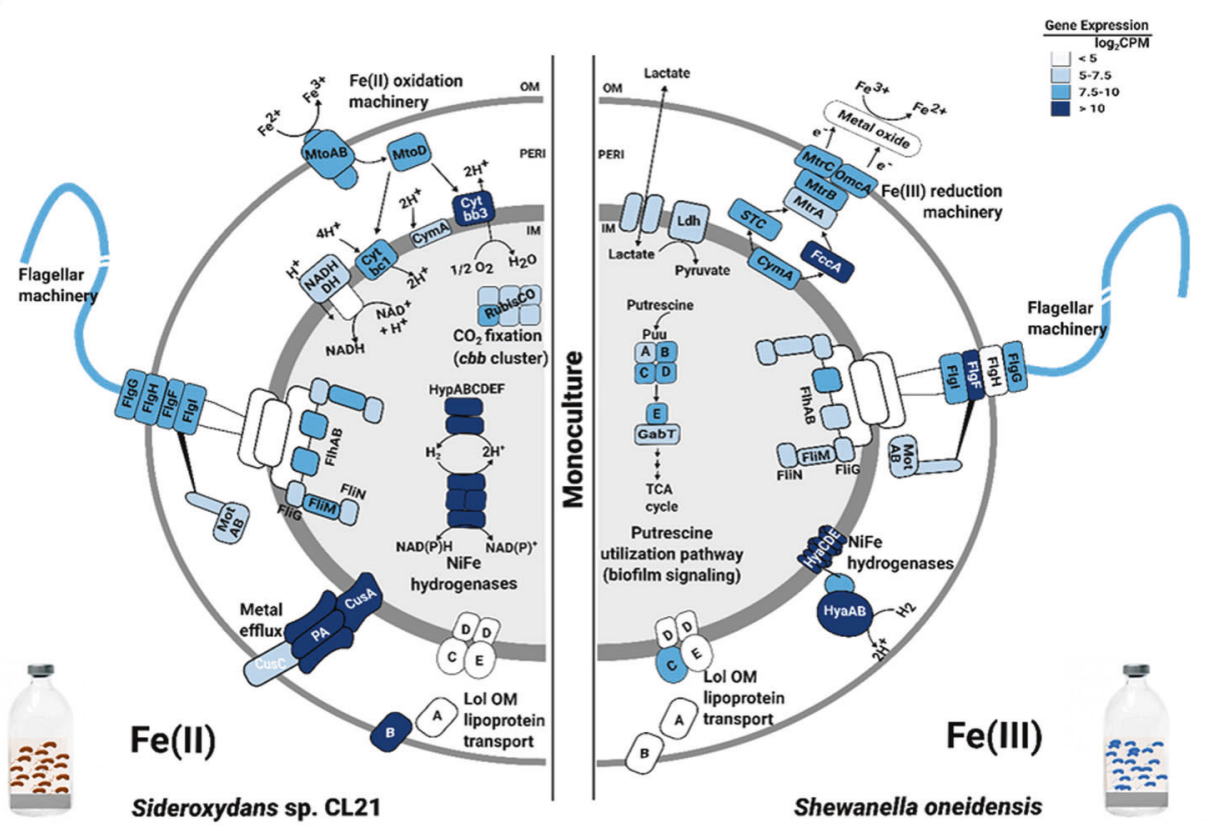

b

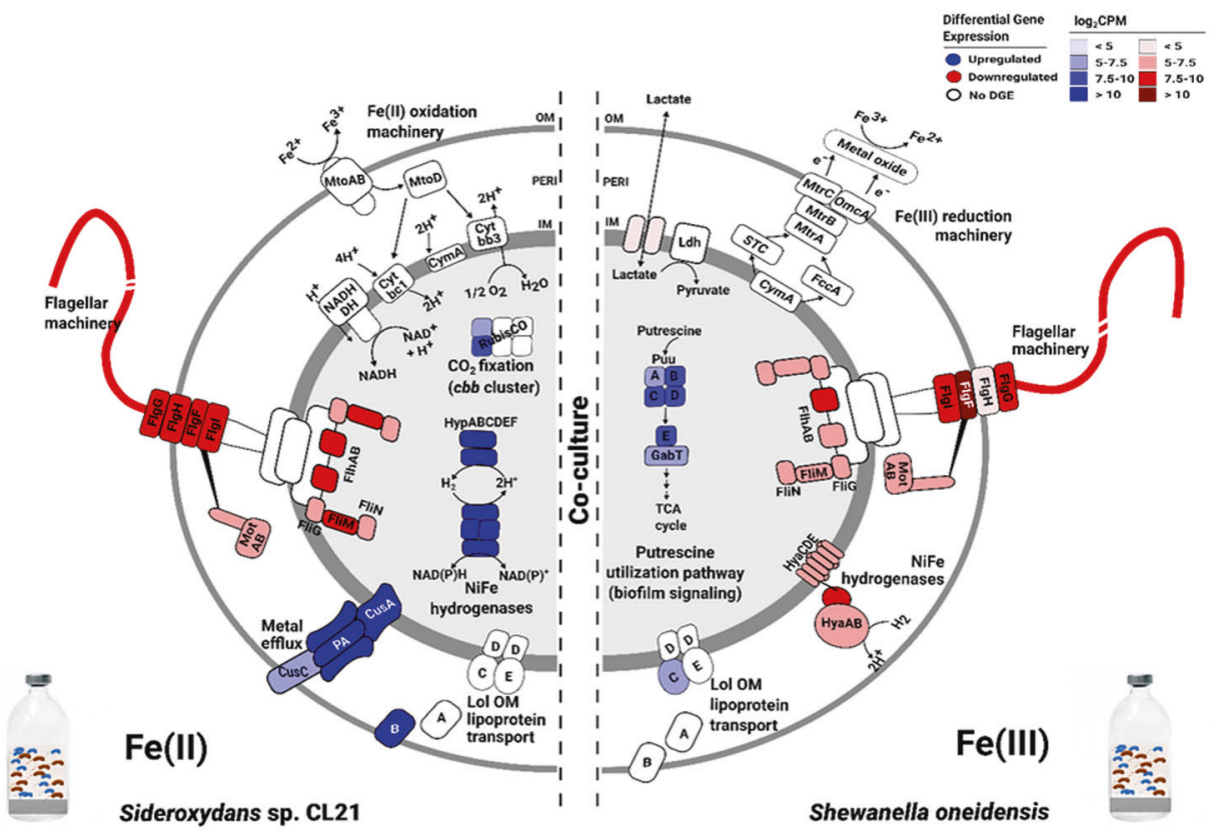

For co-culture incubations, 15.7 and $21.3 \%$ of the total genes were differentially expressed in Sideroxydans sp. CL21 and S. oneidensis, respectively. 927 genes were differentially expressed of which 428 were up- and 499 downregulated in S. oneidensis, compared with 588 genes (249 up-, 338 down-regulated), which were differentially expressed in Sideroxydans sp. CL21 when grown in coculture (Supplementary Fig. S1). Surprisingly, genes involved in $\mathrm{Fe}$ (II) oxidation or $\mathrm{Fe}$ (III) reduction in both partners were not upregulated in co-culture, but were still highly expressed, indicating growth in steady-state (Tables 1, 2; Supplementary Tables S5, S6). The most upregulated genes in $S$. oneidensis include genes encoding putrescine breakdown and an EPS biosynthetic gene cluster, as well as substrate-binding and permease components of zinc and tungstate ABC-type uptake systems. The most downregulated genes encode proteins linked to pilus retraction, type IV pili, and chemotaxis signal transduction (Table 1, Supplementary Table S5). In Sideroxydans sp. CL21, the most upregulated genes code for biopolymer and 
Table 1 Selected differential gene expression changes in $S$. oneidensis in co-culture versus monoculture.

\begin{tabular}{|c|c|c|c|}
\hline \multicolumn{4}{|c|}{ Extracellular electron transfer pathways and accessory genes } \\
\hline Gene ID & Gene & Function & $\begin{array}{l}\log _{2} \mathrm{FC} \text { (fold } \\
\text { change) }\end{array}$ \\
\hline SO_0168 & gspF & T2aSS secretion system inner membrane platform protein & 1.18 \\
\hline SO_0396 & frdC & Quinol-fumarate reductase menaquinol-oxidizing subunit & -2.19 \\
\hline SO_0397 & frdC & Quinol-fumarate reductase menaquinol-oxidizing subunit & -1.02 \\
\hline SO_1778 & $m t r C$ & $\begin{array}{l}\text { Extracellular iron oxide respiratory system surface decaheme } \\
\text { cytochrome c component }\end{array}$ & -1.55 \\
\hline SO_4591 & cymA & Membrane anchored tetraheme cytochrome c & -1.65 \\
\hline \multicolumn{4}{|c|}{ Polyamine Production/Degradation Genes } \\
\hline SO_1274 & риив & Gamma-glutamylputrescine oxidoreductase & 2.49 \\
\hline SO_1275 & рииC & Gamma-glutamyl-gamma-aminobutyraldehyde dehydrogenase & 2.32 \\
\hline SO_1276 & рииE & GABA aminotransferase PLP-dependent & 1.67 \\
\hline SO_3030 & pubA & Putrescine monooxygenase & 1.11 \\
\hline SO_4136 & speC & Ornithine decarboxylase & -1.07 \\
\hline \multicolumn{4}{|c|}{ ABC-type Transport System Genes } \\
\hline SO_0486 & $n o s D$ & ABC-type copper transport system substrate-binding component & -1.05 \\
\hline SO_0565 & $z п и A$ & ABC-type zinc uptake system substrate-binding component & 1.17 \\
\hline SO_0566 & $z n u B$ & ABC-type zinc uptake system permease component & 1.20 \\
\hline SO_1044 & $\operatorname{artI}$ & ABC-type arginine uptake system substrate-binding component & -1.05 \\
\hline SO_3714 & & $\begin{array}{l}\text { ABC-type monosaccharide transport system substrate binding } \\
\text { component }\end{array}$ & -1.11 \\
\hline SO_4318 & $\operatorname{agg} C$ & $\begin{array}{l}\text { Type I protein secretion system bifunctional ATPase and permease } \\
\text { component }\end{array}$ & 1.04 \\
\hline SO_4720 & tup $B$ & ABC-type tungstate uptake system permease component & 1.55 \\
\hline \multicolumn{4}{|c|}{ Motility/Biofilm Formation Genes } \\
\hline SO_0168 & $g s p F$ & T2aSS secretion system inner membrane platform protein & 1.18 \\
\hline SO_3350 & pilU & Pilus retraction ATPase & -1.45 \\
\hline SO_3915 & cheX & Chemotaxis signal transduction system CheY dephosphorylase & -1.49 \\
\hline SO_4053 & & Methyl-accepting chemotaxis protein & -1.16 \\
\hline \multicolumn{4}{|c|}{ Hydrogenase Genes/Energy Metabolism } \\
\hline SO_2092 & hypC & $\mathrm{NiFe}$ hydrogenase assembly chaperone & -1.92 \\
\hline SO_2093 & hyp $B$ & $\begin{array}{l}\mathrm{Ni}^{2+} \text {-binding GTPase involved in regulation of NiFe hydrogenase } \\
\text { expression/maturation }\end{array}$ & -1.50 \\
\hline SO_2097 & hyaC & Periplasmic [Ni-Fe] hydrogenase cytochrome b subunit & -1.04 \\
\hline SO_2096 & hyaD & $\mathrm{NiFe}$ hydrogenase maturation protease & -1.28 \\
\hline SO_2099 & hyaA & Periplasmic $[\mathrm{Ni}-\mathrm{Fe}]$ hydrogenase small subunit & -1.42 \\
\hline
\end{tabular}

Samples were collected from biological replicates at the $6 \mathrm{~d}$ time point. All positive changes (upregulated genes) and negative changes (downregulated genes) shown in Table 1 correspond to differential gene expression patterns in $S$. oneidensis in co-culture in comparison to the gene expression in the monocultures. $p<0.05$ was considered significant. lipoprotein transport, $\mathrm{NiFe}$ hydrogenase incorporation and metallo-center assembly proteins, and hydrogenase- 1 and -2 components. The first couples $\mathrm{H}_{2}$ oxidation in the periplasm to reduction of quinones in the inner membrane, whereas the second is involved in $\mathrm{O}_{2}$ reduction. Motility-related genes and genes associated with NAD-dependent formate dehydrogenase alpha, beta, gamma, and delta subunits and the sulfur carrier protein FdhD were among the most downregulated in Sideroxydans sp. CL21 (Table 2, Supplementary Table S6).

\section{Targeted candidate analyses}

Based on gene expression changes in S. oneidensis, which include gene clusters involved in putrescine and amino acid breakdown, an $\mathrm{ABC}$-type tungsten- and an $\mathrm{ABC}$-type zinc uptake system, we used targeted analyses to examine metabolites linked to these differentially expressed pathways. We detected GABA and evidence of ornithine and arginine [59, 60], all of which are metabolites comprising the putrescine biosynthesis and breakdown pathways. The 
Table 2 Selected differential gene expression changes in Sideroxydans CL21 in co-culture versus monoculture.

Transport/Secretion genes

\begin{tabular}{|c|c|c|c|}
\hline Gene ID & Gene & Function & $\begin{array}{l}\log _{2} \mathrm{FC}(\text { fold } \\
\text { change) }\end{array}$ \\
\hline SidCL21_0513 & $\operatorname{exbD}$ & Biopolymer transport protein ExbD/TolR & 3.74 \\
\hline SidCL21_0918 & lolB & $\begin{array}{l}\text { Outer membrane lipoprotein component of lipoprotein } \\
\text { transport system }\end{array}$ & 2.23 \\
\hline SidCL21_1317 & & $\begin{array}{l}\text { Efflux transport system, outer membrane factor (OMF) } \\
\text { lipoprotein }\end{array}$ & 0.65 \\
\hline SidCL21_0494 & $\operatorname{cusA}$ & $\begin{array}{l}\text { Cobalt-zinc-cadmium resistance protein; cation efflux system } \\
\text { protein }\end{array}$ & 0.73 \\
\hline SidCL21_1055 & $g s p E$ & Predicted secretion system protein & -2.04 \\
\hline SidCL21_1061 & $g s p F$ & & -2.03 \\
\hline \multicolumn{4}{|l|}{ Hydrogenases } \\
\hline SidCL21_0646 & hypA & {$[\mathrm{NiFe}]$ hydrogenase nickel incorporation protein } & 1.63 \\
\hline SidCL21_0647 & hyp B & {$[\mathrm{NiFe}]$ hydrogenase nickel incorporation-associated protein } & 1.84 \\
\hline SidCL21_0649 & hypC & {$[\mathrm{NiFe}]$ hydrogenase metallocenter assembly protein } & 1.42 \\
\hline SidCL21_0650 & hypD & [NiFe] hydrogenase metallocenter assembly protein & 1.41 \\
\hline SidCL21_0651 & hypE & [NiFe] hydrogenase metallocenter assembly protein & 0.91 \\
\hline SidCL21_0648 & hypF & {$[\mathrm{NiFe}]$ hydrogenase metallocenter assembly protein } & 1.56 \\
\hline SidCL21_0636 & hyaB & Uptake [NiFe] hydrogenase, large subunit & 3.10 \\
\hline SidCL21_0637 & hyaC & Uptake [NiFe] hydrogenase, cytochrome b subunit & 3.06 \\
\hline SidCL21_0635 & hyaA & Uptake [NiFe] hydrogenase, small subunit & 2.93 \\
\hline SidCL21_0649 & hyaD & Uptake $[\mathrm{NiFe}]$ hydrogenase, maturation protease & 2.67 \\
\hline SidCL21_1157 & hybA & Hydrogenase- 2 operon protein & 3.05 \\
\hline SidCL21_1156 & $h y b B$ & $\mathrm{Ni} / \mathrm{Fe}$-hydrogenase 2 b-type cytochrome subunit & 2.99 \\
\hline SidCL21_1155 & $h y b C$ & $\mathrm{Ni} / \mathrm{Fe}$-hydrogenase 2 large subunit & 2.85 \\
\hline SidCL21_1158 & hybO & $\mathrm{Ni} / \mathrm{Fe}$-hydrogenase 2 small subunit & 2.79 \\
\hline \multicolumn{4}{|l|}{ Dehydrogenases } \\
\hline SidCL21_0230 & $f d s A$ & NAD-dependent formate dehydrogenase alpha subunit & -1.79 \\
\hline SidCL21_0231 & $f d s B$ & NAD-dependent formate dehydrogenase beta subunit & -3.67 \\
\hline SidCL21_0232 & $f d s G$ & NAD-dependent formate dehydrogenase gamma subunit & -1.68 \\
\hline SidCL21_0739 & & $\mathrm{NAD}(\mathrm{P}) \mathrm{H}$ dehydrogenase & -0.82 \\
\hline SidCL21_2320 & $y k g G$ & $\begin{array}{l}\text { Predicted l-lactate dehydrogenase, hypothetical protein subunit, } \\
\text { Iron-sulfur cluster-binding subunit }\end{array}$ & 1.62 \\
\hline SidCL21_2321 & $y k g F$ & $\begin{array}{l}\text { Predicted l-lactate dehydrogenase, iron-sulfur cluster-binding } \\
\text { subunit }\end{array}$ & 1.36 \\
\hline SidCL21_2319 & $y k g E$ & Predicted 1-lactate dehydrogenase, Fe-S oxidoreductase subunit & 1.11 \\
\hline \multicolumn{4}{|c|}{ Flagellar/Motility/Biofilm Formation Genes } \\
\hline SidCL21_3027 & $f l i$ & Flagellar hook-basal body complex protein & -0.81 \\
\hline SidCL21_0327 & cheY & Chemotaxis regulator & -0.67 \\
\hline SidCL21_3038 & $f l g D$ & Flagellar basal-body rod modification protein & -0.62 \\
\hline \multicolumn{4}{|c|}{ Extracellular Electron Transfer Pathways } \\
\hline SidCL21_0020 & $w r b A$ & Multimeric flavodoxin & -0.86 \\
\hline SidCL21_0462 & & malate:quinone oxidoreductase & 2.14 \\
\hline SidCL21_2568 & & quinolinate synthetase (EC 2.5.1.72) & 1.80 \\
\hline
\end{tabular}

Samples were collected from biological replicates at the $6 \mathrm{~d}$ time point. All positive changes (upregulated genes) and negative changes (downregulated genes) shown in Table 2 correspond to differential gene expression patterns in Sideroxydans sp. CL21 in co-culture in comparison to the gene expression in the monocultures. $p<0.05$ was considered significant. 


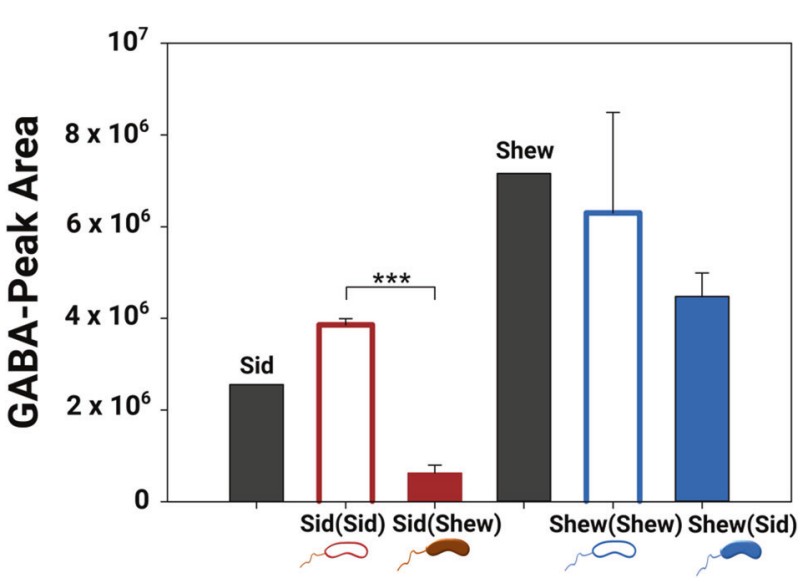

Fig. 5 UHPLC/HRMS based targeted metabolomics profiling. Targeted metabolomics used to quantify the presence of $\gamma$-butanoic acid (GABA), a degradation product in the putrescine biosynthesis pathway, in S. oneidensis MR-1 and Sideroxydans CL21 supernatant exchange experiment. Sid and Shew correspond to Sideroxydans sp. CL21 and S. oneidensis monoculture control incubations, respectively. The labeling of Sid(Sid), Sid(Shew), Shew(Shew) and Shew(Sid) are described in the legend of Fig. 3. Area under the curve of GABA in the supernatant exchange experiment was measured on day 6. Error bars represent the standard deviation of three biological replicates $(n=3)$. Stars indicate significance: $* p<0.05, * * p<0.01$ and $* * * p<0.001$

upregulated pathways are thus responsible for the production of excreted intermediates, but putrescine itself and agmatine, another biosynthetic precursor, were not detected. We also detected GABA, ornithine, and arginine in the supernatant exchange experiment both on day 3 and day 6 . We quantified GABA in supernatant exchange experiments on day 6 (Fig. 5). The amendment of the Sideroxydans sp. CL21 supernatant to $S$. oneidensis did not influence GABA amounts. In contrast, addition of the $S$. oneidensis supernatant to Sideroxydans sp. CL21 led to a significant decrease of GABA ( $t$-test, $p<0.001, n=3$ ) (Fig. 5). No tungsten complexes were identified based on the evaluation of the isotope patterns of the molecular ions. Isotope pattern analysis indicated a metabolite containing complexed zinc. The identification of the metabolite containing complexed $\mathrm{Zn}$ was based on the mass differences between the single isotopic peaks of the substance (with an error $<1 \mathrm{ppm}$ ) and the intensity of the mass peaks was determined according to the abundance of the natural $\mathrm{Zn}$ isotopes. Addition of $S$. oneidensis supernatant to Sideroxydans CL21 as well as the amendment of Sideroxydans CL21 supernatant to S. oneidensis led to reduced levels of the $\mathrm{Zn}$ compound (Fig. S2).

\section{Discussion}

Systematic investigations of Fe-cycling microorganisms were hampered in the past due to their different requirements for oxygen. After methodical optimization, we could merge the growth requirements of a microaerophilic Fe(II)oxidizer and an anaerobic $\mathrm{Fe}(\mathrm{III})$-reducer to study interactions of organisms driving the complete iron wheel. The overall expression levels of genes involved in $\mathrm{Fe}(\mathrm{III})$ reduction in $S$. oneidensis and $\mathrm{Fe}(\mathrm{II})$ oxidation in Sideroxydans sp. CL21 were high under suboxic conditions. Although cell densities of standard monoculture incubations were not reached using this co-culture approach [61-64], we argue that such "candy shop" laboratory conditions do not mimic conditions in nature. Only co-culturing allows investigating the dynamics of interaction mechanisms of naturally co-occurring bacteria.

By combining transcriptomics and metabolomics, we disproved the hypothesis that the expression of genes involved in $\mathrm{Fe}$ (III) reduction and $\mathrm{Fe}$ (II) oxidation is the most affected during co-cultivation. Our data further suggest no acceleration of the iron wheel at all under these conditions. Excreted metabolites promoting growth and $\mathrm{Fe}-$ cycling were the greatest benefit of co-existence. Exometabolites from both $S$. oneidensis and Sideroxydans sp. CL21 elicit a positive effect on growth of their partners, suggesting a mutualistic interaction (Fig. 2). The physical presence of the partner seemed to be less important than the presence of the partner's exometabolome.

Untargeted metabolomics revealed an overall upregulated metabolism of Sideroxydans sp. CL21 from day 3 to 6 when exposed to $S$. oneidensis exudates compared with Sideroxydans sp. CL21 alone (Fig. 3a, b). In contrast, $S$. oneidensis exposed to Sideroxydans sp. CL21 exudates showed a mixed response on day 3 and a predominately downregulated metabolism on day 6 (Fig. 3c, d). Here, the increased performance did not correlate with increased metabolite excretion. Alternatively, S. oneidensis might take up metabolites from the spent medium more efficiently if triggered with exudates from the partner. We found evidence for regulated phenylketone metabolism in Sideroxydans sp. CL21 exposed to $S$. oneidensis supernatant at day 3 and indole metabolism in $S$. oneidensis exposed to Sideroxydans sp. CL21 at day 6. Sugars, amino acids and carboxylic acids were differentially regulated at day 3 , indicating a balanced response of primary metabolism by both partners.

The most differentially expressed genes of both partners grown in co-culture were involved in polyamine biosynthesis and degradation, biofilm formation, motility (i.e., flagella assembly and chemotaxis), utilization of inorganic and organic carbon substrates, and the formation of hydrogenases and dehydrogenases (Fig. 4b). These genes are known to be involved in physiological responses to environmental cues and nutrient availability, however, they are not uniquely related to $\mathrm{Fe}$ (III) reduction or $\mathrm{Fe}$ (II) oxidation.

The genomes of both S. oneidensis and Sideroxydans sp. CL21 encode NiFe hydrogenases, implicating a potential 
competition for $\mathrm{H}_{2}$. Periplasmic NiFe hydrogenases in $S$. oneidensis play a role in both $\mathrm{H}_{2}$ production and oxidation $[65,66]$, while the NiFe hydrogenases in Sideroxydans sp. CL21 enable only $\mathrm{H}_{2}$ oxidation [67]. In iron-rich peatlands, like the Schlöppnerbrunnen fen, $\mathrm{H}_{2}$ concentrations range from 4.5 to $6.0 \%$ in depths up to $40 \mathrm{~cm}[68,69]$. Here $\mathrm{H}_{2}$ appears to be produced by fermenters, with the rhizospheres providing a prime location, and is scavenged by anaerobic secondary fermenters, $\mathrm{Fe}(\mathrm{III})$ reducers, methanogens, and acetogens [68, 70-72]. As Sideroxydans sp. CL21 might be also able to utilize $\mathrm{H}_{2}$ in this fen as an alternative electron donor, variable oxygen concentrations released by plant roots in the rhizosphere and redox fluctuations due to variations in the water table might favor this microaerophile in the interspecies $\mathrm{H}_{2}$ competition. The differential gene expression patterns observed during co-cultivation confirmed interspecific $\mathrm{H}_{2}$ competition. Upregulation of genes encoding various $\mathrm{NiFe}$ hydrogenases in Sideroxydans sp. CL21 suggests the preferred utilization of $\mathrm{H}_{2}$, which serves here as an alternative electron donor to $\mathrm{Fe}(\mathrm{II})$. Simultaneous downregulation of genes encoding hydrogenases in $S$. oneidensis implicates synchronization between these Fecycling microorganisms. To compensate for the lack of $\mathrm{H}_{2}$ as the electron donor, $S$. oneidensis invests in accelerated lactate permease and dehydrogenase expression (Fig. 4b). These orchestrated responses in an environment offering multiple energy sources can even lead to a slowdown of the oxidative part of the iron wheel.

Differential gene expression patterns linked to biofilm formation suggest that Sideroxydans sp. CL21 and S. oneidensis communicate in co-culture using excreted metabolites to coordinate physiology. Biofilm formation was likely triggered by the upregulation of genes involved in the biosynthesis of putrescine and EPS, as well as the downregulation of genes involved in chemotaxis, motility, and type IV pili biosynthesis and activation in S. oneidensis. Detection of GABA, a metabolic product of putrescine, provides additional evidence that polyamines do play a role in microbial interactions [34]. In Sideroxydans sp. CL21, upregulation of genes involved in production and transport of biopolymers and lipoproteins and downregulation of genes involved in flagella machinery biosynthesis and motility are also relevant for biofilm formation during cocultivation. Polyamine signaling in co-culture [73-75] might regulate biofilm formation activity of Sideroxydans sp. CL21. In conclusion, both partners invest in biofilm formation, thus initiating and supporting mutualistic interactions.

Polyamines, including norspermidine, spermidine, and putrescine are known to be required for cell growth and are important signaling molecules. Norspermidine enhances biofilm formation as an extracellular signaling molecule in Vibrio cholerae by interacting with a periplasmic sensor protein and a transmembrane protein [74, 76, 77]. Spermidine and putrescine transporters play a role in surfaceassociated growth of Agrobacterium tumefaciens and Pseudomonas putida [78, 79]. In Yersinia pestis, endogenous putrescine is required for the formation and development of biofilms. Amendment with putrescine rescues biofilm-deficient phenotypes in $Y$. pestis, implicating a role for both endogenous and exogenous putrescine in the activation of biofilm formation [80]. The latter finding is especially important for the current study, such that putrescine produced by $S$. oneidensis might play a dual role as an endogenous signal for biofilm development in $S$. oneidensis and an exogenous signal supporting the same process in Sideroxydans sp. CL21.

Other highly upregulated genes in S. oneidensis include those associated with $\mathrm{ABC}$-type $\mathrm{Zn}$ transporters and $\mathrm{ABC}$ type tungstate uptake systems (Table 1). Zn, an essential micronutrient, is also known to be toxic in excess as being a highly competitive divalent metal capable of displacing weakly bound transition metals in the active sites of metalloenzymes [81]. The observed upregulation of ABCtype $\mathrm{Zn}$ transporters suggests dynamic regulation of $\mathrm{Zn}$ homeostasis to preserve metabolic functioning. The upregulation of genes involved in ABC-type tungstate uptake systems hints that tungsten may function as a cofactor in place of molybdenum for formate dehydrogenases (FDHs) [82, 83]. Interestingly, FDHs can also use FeS clusters, flavins, or cytochromes as cofactors, all of which play a role in $\mathrm{Fe}(\mathrm{III})$ reduction and electron transfer [84]. While the links between tungsten-dependent enzymes and electron transfer in co-cultures are poorly understood, tungsten-containing FDHs are beneficial in certain syntrophic interactions under electroactive conditions [83].

Sideroxydans sp. CL21 and S. oneidensis share homologous Fe-cycling machinery: mto genes in Sideroxydans sp. CL21 and $m t r$ genes in S. oneidensis [17, 27]. In both microorganisms, these gene clusters function as a porin-cytochrome complex forming an electron conduit through the outer membrane via various hemes. This cluster ultimately results in either reduction of Fe (III) outside the cell, coupled to the oxidation of organic carbon or $\mathrm{H}_{2}$ in case of S. oneidensis [28, 29], or the transfer of electrons from $\mathrm{Fe}$ (II) via MtoAB to a molybdoenzyme and subsequently to the respiratory chain (i.e., $c b b_{3}$ or $b d$ oxidase) via CymA [85] in Sideroxydans sp. CL21. The genes encoding MtoAB are located in a gene cluster also containing $m t o D$, a soluble periplasmic cytochrome encoding the protein MtoD, and cymA (homologous to cymA found in S. oneidensis), a quinol oxidoreductase encoding the protein CymA [17, 27]. The $m t o A B$ cluster is also homologous to the pioABC gene cluster in Rhodopseudomonas palustris, which similarly forms a porin-cytochrome conduit [85]. 
Homologs to MtrAB and PioAB are widespread amongst $\mathrm{Fe}(\mathrm{III})$-reducers and $\mathrm{Fe}(\mathrm{II})$-oxidizers widely distributed across Alpha-, Beta-, Gamma-, and Deltaproteobacteria [85] pointing toward possible horizontal gene transfer events. It is believed that $\mathrm{Fe}(\mathrm{III})$ respiration is one of the oldest respiration processes on Earth [86] and aerobic microbial $\mathrm{Fe}(\mathrm{II})$ oxidation became possible billions of years ago when oxygen was released as a byproduct by photosynthetic organisms [85]. Various mechanisms to optimize mutual dependencies including communication might have developed over time when colonizing the same habitat despite seemingly different preferred ecological niches (i.e., microoxic vs. anoxic) $[14,87,88]$. Thus, the homologous Fe-cycling machinery, the ability of both bacteria to positively respond to the partner's diffusive exometabolites concerning activity and growth, and the observation that gene expression is in flux (differentially expressed genes) when these microorganisms are active in co-culture, hints at potential co-evolution.

Our co-cultivation setup provides evidence that $S$. oneidensis is respiring $\mathrm{Fe}(\mathrm{III})$ under suboxic conditions without switching to its preferred terminal electron acceptor, $\mathrm{O}_{2}$. This flexibility allows adjustment to redox gradients and helps to explain the spatial co-existence of Fe-cycling bacteria in a variety of habitats [89-92]. Under fluctuating redox conditions in nature in which these microorganisms must continuously adapt, regulation of exometabolites can become key for Fe-cycling. Acceleration of the iron wheel via optimization of electron donor and electron acceptor availability may not be the most important factor driving their interaction, since $\mathrm{Fe}$ is the fourth most abundant element on Earth [93, 94]. Instead, both partners invest in shaping their environment via biosynthesis and detection of diffusive metabolites. Joint biofilm formation might be more important to ensure access to common goods, such as riboflavin, that function as electron shuttles [95-99]. High abundances of $\mathrm{FeOB}$ and $\mathrm{FeRB}$ have been reported from microbial mats, one of the most well-studied types of biofilms [100]. Simultaneous activity, which we mimicked in our setup, may not be as crucial in nature, where fluctuating redox conditions favor alternately one half of the iron wheel. Temporally decoupled redox processes are the rule and not the exception in nature.

\section{Conclusion}

The results of this study have important implications for the understanding of microbial metal-cycling. Using an integrative transcriptomic and metabolomic approach, we revealed that this Sideroxydans sp. CL21 and S. oneidensis co-culture system can be used as a model system for future investigations focused on the interactions of $\mathrm{Fe}(\mathrm{II})$ oxidizers and $\mathrm{Fe}(\mathrm{III})$ reducers that likely occur in nature and the diffusive metabolites that play a role in these interactions. We provide quantitative evidence that Sideroxydans sp. CL21 and $S$. oneidensis benefit from growth in co-culture, and that diffusive metabolites play a more important role in biogeochemical processes than previously thought. Shaping the environment by a regulated interspecies biofilm formation appears to be the key mechanism underlying interactions of Fe-cycling microorganisms. Characterization of biofilms formed by Sideroxydans sp. CL21 and S. oneidensis during co-cultivation will provide further evidence about the regulation of these interactions, specifically in regards to producing, sharing, and utilizing common goods, such as diffusive chemical mediators and electron shuttles. Our data further demonstrated that competition for $\mathrm{H}_{2}$ between $\mathrm{Fe}$-cycling partners provides another level of metabolic complexity when both partners are simultaneously active. Future incubation studies are needed to prove that Sideroxydans sp. CL21 does, in fact, prefer $\mathrm{H}_{2}$.

\section{Data availability}

The RNA-seq datasets used in this study have been deposited in ArrayExpress under the accession number EMATB-9015 and the Metabolomics datasets have been deposited in MetaboLights under the accession number MTBLS1733.

Acknowledgements This study was part of the Collaborative Research Centre Chemical Mediators in Complex Biosystems (CRC 1127 ChemBioSys) of the Friedrich Schiller University Jena, funded by the Deutsche Forschungsgemeinschaft. We gratefully acknowledge the Fonds der Chemischen Industrie. Additional financial support was provided by the German Centre for Integrative Biodiversity Research (iDiv) Halle-Jena-Leipzig funded by the Deutsche Forschungsgemeinschaft and by the state of Thuringia (2015 FGI 0021) with means of the EU in the framework of the EFRE program. RXP acknowledges funding by the Alexander von Humboldt Foundation. Open access funding provided by Projekt DEAL.

Author contributions KK conceived the study. REC, KK, and GP designed the experiments. REC, SK, NU, and JDW performed the experiments. REC, CEW, KK, SK, GP, RXP, DS, NU, and TW performed the data analyses and/or helped interpret the results. REC wrote the manuscript, with contributions from CEW, KK, SK, GP, $\mathrm{NU}$, and RXP. All co-authors critically reviewed the manuscript and approved the final version.

\section{Compliance with ethical standards}

Conflict of interest The research presented in this manuscript was conducted in the absence of any commercial or financial relationships that could be construed as a potential conflict of interest.

Publisher's note Springer Nature remains neutral with regard to jurisdictional claims in published maps and institutional affiliations. 
Open Access This article is licensed under a Creative Commons Attribution 4.0 International License, which permits use, sharing, adaptation, distribution and reproduction in any medium or format, as long as you give appropriate credit to the original author(s) and the source, provide a link to the Creative Commons license, and indicate if changes were made. The images or other third party material in this article are included in the article's Creative Commons license, unless indicated otherwise in a credit line to the material. If material is not included in the article's Creative Commons license and your intended use is not permitted by statutory regulation or exceeds the permitted use, you will need to obtain permission directly from the copyright holder. To view a copy of this license, visit http://creativecommons. org/licenses/by/4.0/.

\section{References}

1. Ponomarova O, Patil KR. Metabolic interactions in microbial communities: untangling the Gordian knot. Curr Opin Microbiol. 2015;27:37-44.

2. D'Souza G, Shitut S, Preussger D, Yousif G, Waschina S, Kost C. Ecology and evolution of metabolic cross-feeding interactions in bacteria. Nat Prod Rep. 2018;35:455-88.

3. Schink B. Energetics of syntrophic cooperation in methanogenic degradation. Microbiol Mol Biol Rev. 1997;61:262-80.

4. Pernthaler A, Dekas AE, Brown CT, Goffredi SK, Embaye T, Orphan VJ. Diverse syntrophic partnerships from deep-sea methane vents revealed by direct cell capture and metagenomics. Proc Natl Acad Sci USA. 2008;105:7052-7.

5. Men Y, Feil H, Verberkmoes NC, Shah MB, Johnson DR, Lee $\mathrm{PKH}$, et al. Sustainable syntrophic growth of Dehalococcoides ethenogenes strain 195 with Desulfovibrio vulgaris Hildenborough and Methanobacterium congolense: global transcriptomic and proteomic analyses. ISME J. 2012;6:410-21.

6. Zelezniak A, Andrejev S, Ponomarova O, Mende DR, Bork P, Patil KR. Metabolic dependencies drive species co-occurrence in diverse microbial communities. Proc Natl Acad Sci USA. 2015;112:6449-54.

7. Marchal M, Goldschmidt F, Derksen-Müller SN, Panke S, Ackermann M, Johnson DR. A passive mutualistic interaction promotes the evolution of spatial structure within microbial populations. BMC Evol Biol. 2017;17:106.

8. Thompson AW, Foster RA, Krupke A, Carter BJ, Musat N, Vaulot D, et al. Unicellular cyanobacterium symbiotic with a single-celled eukaryotic alga. Science. 2012;337:1546-50.

9. Zengler K, Palsson BO. A road map for the development of community systems (CoSy) biology. Nat Rev Microbiol. 2012;10:366-72.

10. Sachs JL, Hollowell AC. The origins of cooperative bacterial communities. MBio. 2012;3:1-3.

11. Johnson DR, Goldschmidt F, Lilja EE, Ackermann M. Metabolic specialization and the assembly of microbial communities. ISME J. 2012;6:1985-91.

12. Bull JJ, Rice WR. Distinguishing mechanisms for the evolution of co-operation. J Theor Biol. 1991;149:63-74.

13. Foster KR, Wenseleers T. A general model for the evolution of mutualisms. J Evol Biol. 2006;19:1283-93.

14. Weber KA, Achenbach LA, Coates JD. Microorganisms pumping iron: anaerobic microbial iron oxidation and reduction. Nat Rev Microbiol. 2006;4:752-64.

15. Lüdecke $C$, Reiche M, Eusterhues K, Nietzsche S, Küsel K. Acid-tolerant microaerophilic Fe(II)-oxidizing bacteria promote $\mathrm{Fe}(\mathrm{III})$-accumulation in a fen. Environ Microbiol. 2010;12:2814-25.
16. Emerson D, Fleming EJ, McBeth JM. Iron-oxidizing bacteria: an environmental and genomic perspective. Annu Rev Microbiol. 2010;64:561-83

17. Emerson D, Field EK, Chertkov O, Davenport KW, Goodwin L, Munk C, et al. Comparative genomics of freshwater Fe-oxidizing bacteria: implications for physiology, ecology, and systematics. Front Microbiol. 2013;4:254.

18. Fabisch M, Beulig F, Akob DM, Küsel K. Surprising abundance of Gallionella-related iron oxidizers in creek sediments at $\mathrm{pH} 4.4$ or at high heavy metal concentrations. Front Microbiol. 2013;4:390

19. Fleming EJ, Cetinić I, Chan CS, Whitney King D, Emerson D. Ecological succession among iron-oxidizing bacteria. ISME J. 2014;8:804-15.

20. Byrne JM, van der Laan G, Figueroa AI, Qafoku O, Wang C, Pearce CI, et al. Size dependent microbial oxidation and reduction of magnetite nano- and micro-particles. Sci Rep. 2016;6:1-13.

21. Byrne JM, Klueglein N, Pearce C, Rosso KM, Appel E, Kappler A. Redox cycling of $\mathrm{Fe}(\mathrm{II})$ and $\mathrm{Fe}(\mathrm{III})$ in magnetite by $\mathrm{Fe}-$ metabolizing bacteria. Science. 2015;347:1473-6.

22. Braunschweig J, Bosch J, Meckenstock RU. Iron oxide nanoparticles in geomicrobiology: from biogeochemistry to bioremediation. N. Biotechnol. 2013;30:793-802.

23. Bosch J, Heister K, Hofmann T, Meckenstock RU. Nanosized iron oxide colloids strongly enhance microbial iron reduction. Appl Environ Microbiol. 2010;76:184-9.

24. Küsel K, Blöthe M, Schulz D, Reiche M, Drake HL. Microbial reduction of iron and porewater biogeochemistry in acidic peatlands. Biogeosci Discuss. 2008;5:2165-96.

25. Marsili E, Baron DB, Shikhare ID, Coursolle D, Gralnick JA, Bond DR. Shewanella secretes flavins that mediate extracellular electron transfer. Proc Natl Acad Sci USA. 2008;105:3968-73.

26. Royer RA, Burgos WD, Fisher AS, Unz RF, Dempsey BA. Enhancement of biological reduction of hematite by electron shuttling and $\mathrm{Fe}$ (II) complexation. Environ Sci Technol. 2002;36:1939-46.

27. Beckwith CR, Edwards MJ, Lawes M, Shi L, Butt JN, Richardson DJ, et al. Characterization of MtoD from Sideroxydans lithotrophicus: a cytochrome c electron shuttle used in lithoautotrophic growth. Front Microbiol. 2015;6:332.

28. Hartshorne RS, Reardon CL, Ross D, Nuester J, Clarke TA, Gates AJ, et al. Characterization of an electron conduit between bacteria and the extracellular environment. Proc Natl Acad Sci USA. 2009;106:22169-74.

29. White GF, Shi Z, Shi L, Wang Z, Dohnalkova AC, Marshall MJ, et al. Rapid electron exchange between surface-exposed bacterial cytochromes and Fe(III) minerals. Proc Natl Acad Sci USA. 2013;110:6346-51.

30. Venkateswaran K, Moser DP, Dollhopf ME, Lies DP, Saffarini DA, MacGregor BJ, et al. Polyphasic taxonomy of the genus Shewanella and description of Shewanella oneidensis sp. nov. Int J Syst Bacteriol. 1999;49:705-24.

31. Myers CR, Nealson KH. Bacterial manganese reduction and growth with manganese oxide as the sole electron acceptor. Science. 1988;240:1319-21.

32. Myers CR, Nealson KH. Respiration-linked proton translocation coupled to anaerobic reduction of manganese(IV) and iron(III) in Shewanella putrefaciensMR-1. J Bacteriol. 1990;172:6232-8.

33. McBeth JM, Little BJ, Ray RI, Farrar KM, Emerson D. Neutrophilic iron-oxidizing 'Zetaproteobacteria' and mild steel corrosion in nearshore marine environments. Appl Environ Microbiol. 2011;77:1405-12.

34. Mori JF, Ueberschaar N, Lu S, Cooper RE, Pohnert G, Küsel K. Sticking together: inter-species aggregation of bacteria isolated 
from iron snow is controlled by chemical signaling. ISME J. 2017;11:1075-86.

35. Tamura H, Goto K, Yotsuyanagi T, Nagayama M. Spectrophotometric determination of iron(II) with 1,10-phenanthroline in the presence of large amounts of iron(III). Talanta. 1974;21:314-8.

36. Cooper RE, Wegner C-E, McAllister SM, Shevchenko O, Chan CS, Küsel K. Draft genome sequence of Sideroxydanssp. Strain CL21, an $\mathrm{Fe}(\mathrm{II})$-oxidizing bacterium. Microbiol Resour Announc. 2020;9:1-2.

37. Wegner C-E, Gaspar M, Geesink P, Herrmann M, Marz M, Küsel K. Biogeochemical regimes in shallow aquifers reflect the metabolic coupling of the elements nitrogen, sulfur, and carbon. Appl Environ Microbiol. 2019;8:1-19.

38. Andrews S. FastQC: a quality control tool for high throughput sequence data. http://www.bioinformatics.babraham.ac.uk/ projects/fastqc..40.

39. Bushnell B. BBMap short read aligner. https://www.sourceforge. net/projects/bbmap/..41.

40. Kopylova E, Noé L, Touzet H, Noe L, Touzet H. SortMeRNA: fast and accurate filtering of ribosomal RNAs in metatranscriptomic data. Bioinformatics. 2012;28:3211-7.

41. Quast C, Pruesse E, Yilmaz P, Gerken J, Schweer T, Yarza P, et al. The SILVA ribosomal RNA gene database project: improved data processing and web-based tools. Nucleic Acids Res. 2013;41:D590-6.

42. Burge SW, Daub J, Eberhardt R, Tate J, Barquist L, Nawrocki EP, et al. Rfam 11.0: 10 years of RNA families. Nucleic Acids Res. 2013;41:D226-32.

43. Heidelberg JF, Paulsen IT, Nelson KE, Gaidos EJ, Nelson WC, Read TD, et al. Genome sequence of the dissimilatory metal ionreducing bacterium Shewanella oneidensis. Nat Biotechnol. 2002;20:1118-23.

44. Li H, Handsaker B, Wysoker A, Fennell T, Ruan J, Homer N, et al. The sequence alignment/map format and SAM tools. Bioinformatics. 2009;25:2078-9.

45. Liao Y, Smyth GK, Shi W. The Subread aligner: fast, accurate and scalable read mapping by seed-and-vote. Nucleic Acids Res. 2013;41:e108.

46. Liao Y, Smyth GK, Shi W. featureCounts: an efficient general purpose program for assigning sequence reads to genomic features. Bioinformatics. 2014;30:923-30.

47. R Core Team. R: A language and environment for statistical computing. R Foundation for Statistical Computing, Vienna, Austria. 2018

48. Robinson MD, McCarthy DJ, Smyth GK. edgeR: a Bioconductor package for differential expression analysis of digital gene expression data. Bioinformatics. 2010;26:139-40.

49. Tautenhahn R, Patti GJ, Rinehart D, Siuzdak G. XCMS Online: a web-based platform to process untargeted metabolomic data. Anal Chem. 2012;84:5035-9.

50. Stettin D, Poulin RX, Pohnert G. Metabolomics benefits fom orbitrap GC-MS - Comparison of low- and high-resolution GCMS. Metabolites. 2020;10:1-16.

51. Chong J, Yamamoto M, Xia J. MetaboAnalystR 2.0: from raw spectra to biological insights. Metabolites. 2019;9:1-10.

52. Hummel J, Strehmel N, Bölling C, Schmidt S, Walther D, Kopka J. Mass Spectral search and analysis using the golm metabolome database. In: Weckwerth W, Kahl G (eds). The handbook of plant metabolomics. 2013. Wiley-VCH Verlag GmbH \& Co. KGaA, Weinheim, Germany, p. 321-43.

53. Lueder U, Druschel G, Emerson D, Kappler A, Schmidt C. Quantitative analysis of $\mathrm{O}_{2}$ and $\mathrm{Fe}^{2+}$ profiles in gradient tubes for cultivation of microaerophilic Iron(II)-oxidizing bacteria. FEMS Microbiol Ecol. 2018;94:1-15.
54. Lefevre E, Bossa N, Wiesner MR, Gunsch CK. A review of the environmental implications of in situ remediation by nanoscale zero valent iron (nZVI): behavior, transport and impacts on microbial communities. Sci Total Environ. 2016;565:889-901.

55. Kirschling TL, Gregory KB, Minkley EG Jr, Lowry GV, Tilton RD. Impact of nanoscale zero valent iron on geochemistry and microbial populations in trichloroethylene contaminated aquifer materials. Environ Sci Technol. 2010;44:3474-80.

56. Wu S, Cajthaml T, Semerád J, Filipová A, Klementová M, Skála $\mathrm{R}$, et al. Nano zero-valent iron aging interacts with the soil microbial community: a microcosm study. Environ Sci: Nano. 2019;6:1189-206.

57. Auffan M, Rose J, Wiesner MR, Bottero J-Y. Chemical stability of metallic nanoparticles: a parameter controlling their potential cellular toxicity in vitro. Environ Pollut. 2009;157:1127-33.

58. Anza M, Salazar O, Epelde L, Alkorta I, Garbisu C. The application of nanoscale zero-valent iron promotes soil remediation while negatively affecting soil microbial biomass and activity. Front Environ Sci. 2019;7:1-6.

59. Friedrich B, Magasanik B. Enzymes of agmatine degradation and the control of their synthesis in Klebsiella aerogenes. J Bacteriol. 1979; 137:1127-33.

60. Kurihara S, Oda S, Kato K, Kim HG, Koyanagi T, Kumagai H, et al. A novel putrescine utilization pathway involves gammaglutamylated intermediates of Escherichia coli K-12. J Biol Chem. 2005;280:4602-8.

61. Hädrich A, Taillefert M, Akob DM, Cooper RE, Litzba U, Wagner FE, et al. Microbial Fe(II) oxidation by Sideroxydans lithotrophicus ES-1 in the presence of Schlöppnerbrunnen fenderived humic acids. FEMS Microbiol Ecol. 2019;95:1-19.

62. Cooper RE, Eusterhues K, Wegner C-E, Totsche KU, Küsel K. Ferrihydrite-associated organic matter $(\mathrm{OM})$ stimulates reduction by Shewanella oneidensis MR-1 and a complex microbial consortia. Biogeosciences. 2017;14:5171-88.

63. Liu J, Wang Z, Belchik SM, Edwards MJ, Liu C, Kennedy DW, et al. Identification and characterization of MtoA: a decaheme ctype cytochrome of the neutrophilic Fe(II)-oxidizing bacterium Sideroxydans lithotrophicus ES-1. Front Microbiol. 2012;3:37.

64. DiChristina TJ, Moore CM, Haller CA. Dissimilatory Fe(III) and $\mathrm{Mn}(\mathrm{IV})$ reduction by Shewanella putrefaciens requires ferE, a homolog of the pulE ( $g s p E$ ) type II protein secretion gene. J Bacteriol. 2002;184:142-51.

65. Meshulam-Simon G, Behrens S, Choo AD, Spormann AM. Hydrogen metabolism in Shewanella oneidensis MR-1. Appl Environ Microbiol. 2007;73:1153-65.

66. Shi L, Belchik SM, Plymale AE, Heald S, Dohnalkova AC, Sybirna K, et al. Purification and characterization of the [NiFe]hydrogenase of Shewanella oneidensis MR-1. Appl Environ Microbiol. 2011;77:5584-90.

67. Vignais PM, Billoud B, Meyer J. Classification and phylogeny of hydrogenases. FEMS Microbiol Rev. 2001;25:455-501.

68. Reiche M, Torburg G, Küsel K. Competition of Fe(III) reduction and methanogenesis in an acidic fen. FEMS Microbiol Ecol. 2008;65:88-101.

69. Reiche M, Haedrich A, Lischeid G, Kuesel K, Hädrich A, Lischeid G, et al. Impact of manipulated drought and heavy rainfall events on peat mineralization processes and source-sink functions of an acidic fen. J Geophys Res-Biogeosci. 2009; 114:1-13.

70. Hädrich A, Heuer VB, Herrmann M, Hinrichs K-U, Küsel K. Origin and fate of acetate in an acidic fen. FEMS Microbiol Ecol. 2012;81:339-54.

71. Hamberger A, Horn MA, Dumont MG, Murrell JC, Drake HL. Anaerobic consumers of monosaccharides in a moderately acidic fen. Appl Environ Microbiol. 2008;74:3112-20. 
72. Wüst PK, Horn MA, Drake HL. Trophic links between fermenters and methanogens in a moderately acidic fen soil. Environ Microbiol. 2009;11:1395-409.

73. Tabor CW, Tabor H. Polyamines. Annu Rev Biochem. 1984;53:749-90.

74. Karatan E, Watnick P. Signals, regulatory networks, and materials that build and break bacterial biofilms. Microbiol Mol Biol Rev. 2009;73:310-47.

75. Bachrach U, Heimer YM. The physiology of polyamines. 1989. CRC Press Taylor and Francis Group, Boca Raton, FL, USA.

76. Karatan E, Duncan TR, Watnick PI. NspS, a predicted polyamine sensor, mediates activation of Vibrio cholerae biofilm formation by norspermidine. J Bacteriol. 2005;187:7434-43.

77. Cockerell SR, Rutkovsky AC, Zayner JP, Cooper RE, Porter LR, Pendergraft SS, et al. Vibrio cholerae NspS, a homologue of ABC-type periplasmic solute binding proteins, facilitates transduction of polyamine signals independent of their transport. Microbiology. 2014;160:832-43.

78. Matthysse AG, Yarnall HA, Young N. Requirement for genes with homology to $\mathrm{ABC}$ transport systems for attachment and virulence of Agrobacterium tumefaciens. J Bacteriol. 1996;178:5302-8.

79. Sauer K, Camper AK. Characterization of phenotypic changes in Pseudomonas putida in response to surface-associated growth. J Bacteriol. 2001;183:6579-89.

80. Patel CN, Wortham BW, Lines JL, Fetherston JD, Perry RD, Oliveira MA. Polyamines are essential for the formation of plague biofilm. J Bacteriol. 2006;188:2355-63.

81. Capdevila DA, Wang J, Giedroc DP. Bacterial strategies to maintain zinc metallostasis at the host-pathogen interface. J Biol Chem. 2016;291:20858-68.

82. Schoepp-Cothenet B, van Lis R, Philippot P, Magalon A, Russell MJ, Nitschke W. The ineluctable requirement for the trans-iron elements molybdenum and/or tungsten in the origin of life. Sci Rep. 2012;2:263.

83. Reda T, Plugge CM, Abram NJ, Hirst J. Reversible interconversion of carbon dioxide and formate by an electroactive enzyme. Proc Natl Acad Sci USA. 2008;105:10654-8.

84. Hartmann T, Schwanhold N, Leimkühler S. Assembly and catalysis of molybdenum or tungsten-containing formate dehydrogenases from bacteria. Biochim Biophys Acta. 2015;1854:1090-1100.

85. Ilbert M, Bonnefoy V. Insight into the evolution of the iron oxidation pathways. Biochim Biophys Acta. 2013;1827:161-75.

86. Lovley DR, Holmes DE, Nevin KP. Dissimilatory Fe(III) and Mn(IV) reduction. Adv Micro Physiol. 2004;49:219-86.
87. Melton ED, Swanner ED, Behrens S, Schmidt C, Kappler A. The interplay of microbially mediated and abiotic reactions in the biogeochemical Fe cycle. Nat Rev Microbiol. 2014;12:797-808.

88. Maisch M, Lueder U, Laufer K, Scholze C, Kappler A, Schmidt C. Contribution of microaerophilic Iron(II)-oxidizers to Iron(III) mineral formation. Environ Sci Technol. 2019;53:8197-204.

89. Hong Y, Wu J, Wilson S, Song B. Vertical stratification of sediment microbial communities along geochemical gradients of a subterranean estuary located at the Gloucester Beach of Virginia, United States. Front Microbiol. 2018;9:3343.

90. Liptzin D, Silver WL. Spatial patterns in oxygen and redox sensitive biogeochemistry in tropical forest soils. Ecosphere. 2015;6:art211.

91. Borer B, Tecon R, Or D. Spatial organization of bacterial populations in response to oxygen and carbon counter-gradients in pore networks. Nat Commun. 2018;9:769.

92. Widder S, Allen RJ, Pfeiffer T, Curtis TP, Wiuf C, Sloan WT, et al. Challenges in microbial ecology: building predictive understanding of community function and dynamics. ISME J. 2016;10:2557-68.

93. Frey PA, Reed GH. The ubiquity of iron. ACS Chem Biol. 2012;7:1477-81.

94. Edwards KJ, Bach W, McCollom TM, Rogers DR. Neutrophilic iron-oxidizing bacteria in the ocean: their habitats, diversity, and roles in mineral deposition, rock alteration, and biomass production in the deep-sea. Geomicrobiol J. 2004;21:393-404.

95. Bondici VF, Khan NH, Swerhone GDW, Dynes JJ, Lawrence JR, Yergeau E, et al. Biogeochemical activity of microbial biofilms in the water column overlying uranium mine tailings. J Appl Microbiol. 2014;117:1079-94.

96. Lee AK, Newman DK. Microbial iron respiration: impacts on corrosion processes. Appl Microbiol Biotechnol. 2003;62:134-9.

97. Glasser NR, Saunders SH, Newman DK. The colorful world of extracellular electron shuttles. Annu Rev Microbiol. 2017;71:731-51.

98. Philips J, Verbeeck K, Rabaey K, Arends JBA. Electron transfer mechanisms in biofilms. In: Scott K, Yu EH (eds). Microbial electrochemical and fuel cells. 2016. Woodhead Publishing, Sawston, Cambridge, United Kingdom, p. 67-113.

99. Gao L, Lu X, Liu H, Li J, Li W, Song R, et al. Mediation of extracellular polymeric substances in microbial reduction of hematite by Shewanella oneidensis MR-1. Front Microbiol. 2019;10:575.

100. Roden EE, McBeth JM, Blöthe M, Percak-Dennett EM, Fleming EJ, Holyoke RR, et al. The microbial ferrous wheel in a neutral pH groundwater seep. Front Microbiol. 2012;3:172. 